\title{
Selective One-Step Synthesis of Dimethoxymethane via Methanol or Dimethyl Ether Oxidation on $\mathrm{H}_{3+n} \mathrm{~V}_{n} \mathrm{Mo}_{12-n} \mathrm{PO}_{40}$ Keggin Structures
}

\author{
Haichao Liu and Enrique Iglesia* \\ Department of Chemical Engineering, University of California at Berkeley, Berkeley, California 94720
}

Received: January 31, 2003; In Final Form: July 10, 2003

\begin{abstract}
The one-step selective synthesis of dimethoxymethane (DMM; $\mathrm{CH}_{3} \mathrm{OCH}_{2} \mathrm{OCH}_{3}$ ) was achieved by oxidation of dimethyl ether (DME) or methanol $\left(\mathrm{CH}_{3} \mathrm{OH}\right)$ with $\mathrm{O}_{2}$ at low temperatures $(453-513 \mathrm{~K})$ on unsupported and $\mathrm{SiO}_{2}$-supported heteropolyacids with Keggin structures $\left[\mathrm{H}_{3+n} \mathrm{PV}_{n} \mathrm{Mo}_{12-n} \mathrm{O}_{40}(n=0-4)\right]$. These materials provide redox and Brönsted acid sites required for bifunctional DMM synthesis pathways. Supported structures at submonolayer coverages $\left(0.1-0.28\right.$ Keggin units per $\left.\mathrm{nm}^{2}\right)$ are much more accessible than bulk structures and remove diffusional constraints. Their higher dispersions lead to marked improvements in DMM synthesis rates and selectivities and to lower $\mathrm{CO}_{x}$ yields using either $\mathrm{CH}_{3} \mathrm{OH}$ or DME reactants. The presence of $\mathrm{H}_{2} \mathrm{O}$ during DME oxidation increases DMM synthesis rates because of a consequent increase in the rate of DME hydrolysis reactions, which form $\mathrm{CH}_{3} \mathrm{OH}$ molecules required as intermediates in the DMM synthesis reaction sequence. Pure $\mathrm{CH}_{3} \mathrm{OH}$ reactants form DMM at much higher rates than DME reactants. The replacement of some Mo atoms in $\mathrm{H}_{3} \mathrm{PMo}_{12} \mathrm{O}_{40}$ structures with $\mathrm{V}$ increases DMM synthesis rates and selectivities while inhibiting the formation of $\mathrm{CO}_{x}$. In fact, $\mathrm{CO}_{x}$ was not detected on $\mathrm{H}_{3+}{ }_{n} \mathrm{PV}_{n} \mathrm{Mo}_{12-n} \mathrm{O}_{40}(n=2,4 ; \sim 0.1 \mathrm{KU} /$ $\mathrm{nm}^{2}$ ) even at high $\mathrm{CH}_{3} \mathrm{OH}$ conversions $(\sim 50 \%)$. $\mathrm{CH}_{3} \mathrm{OH}$ converts to DMM via primary $\mathrm{CH}_{3} \mathrm{OH}$ reactions to form formaldehyde $\left(\mathrm{HCHO}\right.$ ) and subsequent secondary reactions of $\mathrm{HCHO}$ with $\mathrm{CH}_{3} \mathrm{OH}$ in steps requiring both redox and acid sites; $\mathrm{CH}_{3} \mathrm{OH}$ also reacts to form DME on acid sites. These pathways are consistent with the effects of changes in residence time and of the partial removal of acidic $\mathrm{OH}$ groups from Keggin structures on reaction selectivities. High $\mathrm{CH}_{3} \mathrm{OH}$ pressures and conversions favor $\mathrm{HCHO}-\mathrm{CH}_{3} \mathrm{OH}$ acetalization reactions and DMM synthesis rates and selectivities. Thermal treatments that cause dehydroxylation and loss of Brönsted acid sites without destroying the primary Keggin structures decrease DME formation rates without significant changes in DMM synthesis rates. These findings suggest that acid sites are not involved in the rate-limiting step for DMM synthesis and that much higher DMM selectivities can be achieved by further increases in the ratio of the rates of redox and acid catalysis. This study represents the first report of high DMM selectivity and yields on stable molecular oxide clusters and provides an effective approach to the rational design of oxide materials for the one-step synthesis of dimethoxymethane from either dimethyl ether or methanol.
\end{abstract}

\section{Introduction}

Dimethoxymethane (DMM; $\mathrm{CH}_{3} \mathrm{OCH}_{2} \mathrm{OCH}_{3}$ ) is an important chemical intermediate. It is used as a gasoline additive, as a building block in organic syntheses, and as a precursor in the synthesis of concentrated formaldehyde (HCHO) streams and of polyoxymethylene dimethyl ethers useful as diesel fuel additives. DMM can be formed from $\mathrm{HCHO}$ produced via $\mathrm{CH}_{3^{-}}$ $\mathrm{OH}$ oxidation reactions. In contrast with the many previous studies of $\mathrm{CH}_{3} \mathrm{OH}$ oxidation to formaldehyde, the one-stage syntheses of DMM from $\mathrm{CH}_{3} \mathrm{OH}$

$$
3 \mathrm{CH}_{3} \mathrm{OH}+{ }^{1} / 2 \mathrm{O}_{2} \rightarrow \mathrm{CH}_{3} \mathrm{OCH}_{2} \mathrm{OCH}_{3}+2 \mathrm{H}_{2} \mathrm{O}
$$

or dimethyl ether (DME) have received limited attention and achieved limited success. Current state-of-the-art DMM synthesis processes involve methanol oxidation to formaldehyde on silver or iron molybdate catalysts, followed by subsequent condensation reactions of methanol-formaldehyde mixtures using sulfuric acid or solid acid catalysts. ${ }^{1,2}$ Iwasawa et al. ${ }^{3,4}$ have recently reported that $\mathrm{ReO}_{x}$-based catalysts with high $\mathrm{Re}$

* To whom all correspondence should be addressed. E-mail: iglesia@ cchem.berkeley.edu. Tel: (510) 642-9673. Fax: (510) 642-4778. content ( $\sim 10$ wt \%) selectively oxidize methanol to DMM with much higher rates and selectivities than $\mathrm{V}_{2} \mathrm{O}_{5} / \mathrm{TiO}_{2}$, molybdophosphoric acid, or $\mathrm{MoO}_{3} / \mathrm{MCM}-41,{ }^{5-7}$ typically used for $\mathrm{CH}_{3} \mathrm{OH}$ oxidation to $\mathrm{HCHO}$. The high cost of $\mathrm{ReO}_{x}$ and its volatility at the required reaction temperatures $(\sim 473-593 \mathrm{~K})$ present significant hurdles to the application of this first and only example of a single-stage selective synthesis of dimethoxymethane.

Two types of active sites appear to be required for DMM synthesis. Redox sites with active lattice oxygen atoms are involved in the initial formation of $\mathrm{HCHO}$ from $\mathrm{CH}_{3} \mathrm{OH}$ or DME, whereas acid sites can catalyze desired acetalization reactions of $\mathrm{HCHO}$ and $\mathrm{CH}_{3} \mathrm{OH}$, and also $\mathrm{CH}_{3} \mathrm{OH}-\mathrm{CH}_{3} \mathrm{OCH}_{3}$ interconversion side reactions. Heteropolyacids are negatively charged oxide clusters with Keggin structures, W, Mo, or V addenda atoms, and $\mathrm{P}, \mathrm{Si}$, or $\mathrm{B}$ as central atoms. ${ }^{8-10}$ The negative charge is balanced by cations, which renders the materials acidic when protons become the charge-balancing cations. These solids contain both acid and redox functionalities, but typically form secondary crystalline structures with low surface area $\left(<10 \mathrm{~m}^{2} / \mathrm{g}\right)$; they would represent attractive potential catalysts for DMM synthesis if their surface area and 
TABLE 1: DME Oxidation at $513 \mathrm{~K}$ on Unsupported and $\mathrm{SiO}_{2}$-Supported Heteropolyacid Catalysts $\left(80 \mathrm{kPa}\right.$ DME, $18 \mathrm{kPa} \mathrm{O}_{2}$, $2 \mathrm{kPa} \mathrm{N}_{2}$, balance $\mathrm{He}$ )

\begin{tabular}{|c|c|c|c|c|c|c|c|c|}
\hline \multirow[b]{2}{*}{ catalyst } & \multirow{2}{*}{$\begin{array}{l}\text { DME conversion } \\
(\%)^{a}\end{array}$} & \multirow{2}{*}{$\begin{array}{c}\text { rate } \\
(\text { DME molecules/ } \\
\text { KU-h) }{ }^{a} \\
\end{array}$} & \multirow{2}{*}{$\begin{array}{c}\text { rate } \\
\text { (mol DME/ }^{\text {g-metal-h) }}{ }^{a}\end{array}$} & \multicolumn{5}{|c|}{ selectivity $(\%)^{a}$} \\
\hline & & & & $\overline{\mathrm{CH}_{3} \mathrm{OH}}$ & $\mathrm{HCHO}$ & MF & DMM & $\overline{\mathrm{CO}_{x}}$ \\
\hline $\mathrm{H}_{3} \mathrm{PMo}_{12} \mathrm{O}_{40}$ & $\begin{array}{c}2.0 \\
(1.8)\end{array}$ & $\begin{array}{l}10.1 \\
(9.2)\end{array}$ & $\begin{array}{c}8.4 \\
(7.6)\end{array}$ & 9.9 & $\begin{array}{c}2.8 \\
(3.1)\end{array}$ & $\begin{array}{c}16.7 \\
(18.5)\end{array}$ & $\begin{array}{c}46.0 \\
(51.1)\end{array}$ & $\begin{array}{c}24.5 \\
(27.2)\end{array}$ \\
\hline $\mathrm{H}_{5} \mathrm{PV}_{2} \mathrm{Mo}_{10} \mathrm{O}_{40}$ & $\begin{array}{l}1.8 \\
(1.6)\end{array}$ & $\begin{array}{l}4.4 \\
(3.8)\end{array}$ & $\begin{array}{c}4.2 \\
(3.6)\end{array}$ & 13.1 & $\begin{array}{c}14.8 \\
(17.0)\end{array}$ & $\begin{array}{c}0.3 \\
(0.3)\end{array}$ & $\begin{array}{c}56.8 \\
(65.4)\end{array}$ & $\begin{array}{c}14.9 \\
(17.1)\end{array}$ \\
\hline $\mathrm{H}_{3} \mathrm{PW}_{12} \mathrm{O}_{40}$ & 0.9 & 1.3 & 0.6 & 86.8 & 3.7 & 0 & 6.9 & 2.5 \\
\hline $\begin{array}{l}\mathrm{H}_{3} \mathrm{PMo}_{12} \mathrm{O}_{40} / \mathrm{SiO}_{2} \\
(9.3 \mathrm{wt} \%)\end{array}$ & $\begin{array}{l}2.3 \\
(2.2)\end{array}$ & $\begin{array}{l}125.3 \\
(117.4)\end{array}$ & $\begin{array}{l}103.5 \\
(96.9)\end{array}$ & 6.3 & $\begin{array}{l}22.0 \\
(23.5)\end{array}$ & $\begin{array}{c}15.0 \\
(16.0)\end{array}$ & $\begin{array}{c}44.6 \\
(47.6)\end{array}$ & $\begin{array}{c}9.4 \\
(10.0)\end{array}$ \\
\hline $\begin{array}{l}\mathrm{H}_{5} \mathrm{PV}_{2} \mathrm{Mo}_{10} \mathrm{O}_{40} / \mathrm{SiO}_{2} \\
(9.2 \mathrm{wt} \%)\end{array}$ & $\begin{array}{l}1.8 \\
(1.7)\end{array}$ & $\begin{array}{c}47.7 \\
(44.2)\end{array}$ & $\begin{array}{c}45.5 \\
(42.1)\end{array}$ & 7.4 & $\begin{array}{l}33.2 \\
(35.9)\end{array}$ & $\begin{array}{c}2.6 \\
(2.8)\end{array}$ & $\begin{array}{c}55.0 \\
(59.4)\end{array}$ & $\begin{array}{c}1.8 \\
(1.9)\end{array}$ \\
\hline
\end{tabular}

${ }^{a}$ Data in parentheses are calculated on a $\mathrm{CH}_{3} \mathrm{OH}$-free basis.

redox properties could be improved significantly without excessive loss of required Brönsted acid sites.

Heteropolyacids containing $\mathrm{W}$ as an addenda atom convert $\mathrm{CH}_{3} \mathrm{OH}$ to DME via dehydration reactions catalyzed by Brönsted acid sites, without significant contributions from redox pathways leading to $\mathrm{HCHO}$ or DMM. ${ }^{11}$ Mo-containing heteropolyacids with central $\mathrm{Si}$ or $\mathrm{P}$ atoms catalyze methanol conversion to formaldehyde with minor amounts of DMM side products. ${ }^{6,11}$ Here, we report the discovery of very active $\mathrm{H}_{3}$ $\mathrm{PMo}_{12} \mathrm{O}_{40}$ and $\mathrm{H}_{3+n} \mathrm{PMo}_{12-n} \mathrm{~V}_{n} \mathrm{O}_{40}$ structures supported on $\mathrm{SiO}_{2}$, which catalyze $\mathrm{CH}_{3} \mathrm{OH}$ reactions at low temperatures with very high selectivities to DMM (80-96\%, DME-free basis) and high $\mathrm{CH}_{3} \mathrm{OH}$ conversions (20-40\%, DME-free basis). These materials also catalyze DMM synthesis from DME $\left(3 \mathrm{CH}_{3} \mathrm{OCH}_{3}+\right.$ $\mathrm{O}_{2} \rightarrow 2 \mathrm{CH}_{3} \mathrm{OCH}_{2} \mathrm{OCH}_{3}+\mathrm{H}_{2} \mathrm{O}$ ) or DME $-\mathrm{CH}_{3} \mathrm{OH}$ reactants. DME and DME- $\mathrm{CH}_{3} \mathrm{OH}$ reactants can be produced less expensively from synthesis gas $\left(\mathrm{CO} / \mathrm{H}_{2}\right)$ than chemical grade $\mathrm{CH}_{3} \mathrm{OH},{ }^{12-14}$ which is currently used in the synthesis of intermediate chemicals.

\section{Experimental Section}

Supported heteropolyacid catalysts were prepared by incipient wetness impregnation of $\mathrm{SiO}_{2}$ (Cab-O-Sil, $\left.288 \mathrm{~m}^{2} / \mathrm{g}\right)$ with methanolic (Merck, 99.98\%) solutions of each heteropolyacid $\left\{\mathrm{H}_{3+x} \mathrm{PV}_{x} \mathrm{Mo}_{12-x} \mathrm{O}_{40} \cdot 30 \mathrm{H}_{2} \mathrm{O}(x=0,1,2,4)\right.$, Japan New Metals Co.; $\mathrm{H}_{3} \mathrm{PW}_{12} \mathrm{O}_{40} \cdot 6 \mathrm{H}_{2} \mathrm{O}$, Allen Chem. $\}$ at $298 \mathrm{~K}$ for $5 \mathrm{~h}$. Impregnated samples were then dried in ambient air at $393 \mathrm{~K}$ overnight.

Raman spectra were measured using a HoloLab 5000 Raman spectrometer (Kaiser Optical) and a frequency-doubled Nd:YAG laser at a wavelength of $532 \mathrm{~nm}$. The Raman spectrometer was equipped with a CCD camera that was electrically cooled to $233 \mathrm{~K}$ in order to reduce thermal noise. Samples were pressed into self-supporting thin wafers, placed on a rotary stage within a quartz cell, and spun at $\sim 16 \mathrm{~Hz}$ to avoid structural changes caused by local laser heating. Raman spectra were measured for fresh samples and for samples treated in flowing 20\% $\mathrm{O}_{2} /$ $\mathrm{He}\left(\mathrm{O}_{2}\right.$, Praxair, 99.999\%; He, Airgas, 99.999\%; $\left.0.67 \mathrm{~cm}^{3} / \mathrm{s}\right)$ at several temperatures for $1 \mathrm{~h}$.

Dimethyl ether and methanol reactions were carried out at $453-533 \mathrm{~K}$ in a fixed-bed quartz microreactor containing catalyst powders $(0.1-0.3 \mathrm{~g})$ diluted with ground quartz in order to prevent temperature nonuniformities. Samples were treated in flowing $20 \% \mathrm{O}_{2} / \mathrm{He}\left(\mathrm{O}_{2}\right.$, Praxair, 99.999\%; He, Airgas, $\left.99.999 \% ; 0.67 \mathrm{~cm}^{3} / \mathrm{s}\right)$ for $1.0 \mathrm{~h}$ before catalytic reaction measurements. The reactant mixture consisted of $80 \mathrm{kPa}$ DME (Praxair, 99.5\%), $18 \mathrm{kPa} \mathrm{O}_{2}$, and $2 \mathrm{kPa} \mathrm{N}_{2}$ (Praxair, Certified $\mathrm{O}_{2} / \mathrm{N}_{2}$ mixture) for DME reactions, and $4 \mathrm{kPa} \mathrm{CH} 3 \mathrm{OH}$ (Merck, 99.98\%), $9 \mathrm{kPa} \mathrm{O}_{2}, 1 \mathrm{kPa} \mathrm{N} \mathrm{N}_{2}$ (Praxair, Certified $\mathrm{O}_{2} / \mathrm{N}_{2}$ mixture), and $86 \mathrm{kPa}$ balance $\mathrm{He}$ (Airgas, 99.999\%) for $\mathrm{CH}_{3} \mathrm{OH}$ oxidation reactions. $\mathrm{CH}_{3} \mathrm{OH}$ was introduced by bubbling $\mathrm{He}$ gas through a glass saturator filled with liquid $\mathrm{CH}_{3} \mathrm{OH}$. For kinetic measurements, $\mathrm{CH}_{3} \mathrm{OH}$ and $\mathrm{O}_{2}$ partial pressures were varied in the range 2-30 $\mathrm{kPa}$, and 5-30 $\mathrm{kPa}$, respectively. Homogeneous DME or $\mathrm{CH}_{3} \mathrm{OH}$ reactions were not detected for the conditions used in this study. All transfer lines between the reactor and gas chromatograph were kept above $393 \mathrm{~K}$ in order to avoid condensation of reaction products. Reactants and products were analyzed by on-line gas chromatography (Hewlett-Packard 6890GC) using a methyl-silicone capillary (HP-1 with $30 \mathrm{~m} \times$ $0.25 \times 0.25 \mu \mathrm{m}$ film thickness) column and a Porapak Q packed column (80-100 mesh, $1.82 \mathrm{~m} \times 3.18 \mathrm{~mm}$ ) connected to flame ionization and thermal conductivity detectors, respectively. Selectivities are reported on a carbon basis as the percentage of the converted reactant appearing as a given product.

\section{Results and Discussion}

3.1 Catalytic Oxidation of Dimethyl Ether on Heteropolyacids with Keggin Structures. Table 1 shows dimethyl ether (DME) reaction rates and selectivities at $513 \mathrm{~K}, 80 \mathrm{kPa} \mathrm{DME}$, and $20 \mathrm{kPa} \mathrm{O}_{2}$ on unsupported and $\mathrm{SiO}_{2}$-supported $\mathrm{H}_{3} \mathrm{PMo}_{12} \mathrm{O}_{40}$ and $\mathrm{H}_{5} \mathrm{PV}_{2} \mathrm{Mo}_{10} \mathrm{O}_{40}$ catalysts (treated at $553 \mathrm{~K}$ ). On both unsupported samples, dimethoxymethane (DMM) was the most abundant reaction product. Reaction rates were normalized per Keggin unit (DME molecules/KU-h) or per gram of $\mathrm{V}$ and Mo (mmol/g-metal-h). Reaction rates and selectivities were calculated by considering $\mathrm{CH}_{3} \mathrm{OH}$ as a product and as a result, they are reported on a $\mathrm{CH}_{3} \mathrm{OH}$-free basis. At similar DME conversions $(\sim 2 \%)$, reaction rates were about two times greater on $\mathrm{H}_{3} \mathrm{PMo}_{12} \mathrm{O}_{40}$ than on $\mathrm{H}_{5} \mathrm{PV}_{2} \mathrm{Mo}_{10} \mathrm{O}_{40}$, but $\mathrm{H}_{5} \mathrm{PV}_{2} \mathrm{Mo}_{10} \mathrm{O}_{40}$ was more selective to desired partial oxidation products $\mathrm{HCHO}$ (14.8\% vs $2.8 \%)$ and DMM (56.8\% vs.46.0\%), and formed less $\mathrm{CO}_{x}\left(\mathrm{CO}+\mathrm{CO}_{2} ;>90 \%\right.$ of $\mathrm{CO}_{x}$ molecules are $\mathrm{CO}$ at all reaction conditions) (14.9\% vs $24.5 \%$ ). Methylformate (MF) selectivities were much higher on $\mathrm{H}_{3} \mathrm{PMo}_{12} \mathrm{O}_{40}(16.7 \%)$ than on $\mathrm{H}_{5} \mathrm{PV}_{2}-$ $\mathrm{Mo}_{10} \mathrm{O}_{40}(0.3 \%)$. For comparison, the results obtained on $\mathrm{H}_{3}$ $\mathrm{PW}_{12} \mathrm{O}_{40}$ are also included in Table $1 . \mathrm{H}_{3} \mathrm{PW}_{12} \mathrm{O}_{40}$ catalysts formed mostly $\mathrm{CH}_{3} \mathrm{OH}$ from DME with only traces of $\mathrm{HCHO}$ and DMM, consistent with their strong acidity and unreducible nature. ${ }^{9,10}$

Supporting $\mathrm{H}_{3} \mathrm{PMo}_{12} \mathrm{O}_{40}\left(\mathrm{PMo}_{12}\right)$ and $\mathrm{H}_{5} \mathrm{PV}_{2} \mathrm{Mo}_{10} \mathrm{O}_{40}\left(\mathrm{PV}_{2}-\right.$ $\mathrm{Mo}_{10}$ ) on $\mathrm{SiO}_{2}$ led to significantly higher DME oxidation reaction rates, as expected from their greater accessibility compared with their respective crystalline bulk structures (Table 1). At similar surface densities and DME conversions, $\mathrm{H}_{3^{-}}$ $\mathrm{PMo}_{12} \mathrm{O}_{40} / \mathrm{SiO}_{2}$ showed higher DME reaction rates than $\mathrm{H}_{5} \mathrm{PV}_{2}-$ $\mathrm{Mo}_{10} \mathrm{O}_{40} / \mathrm{SiO}_{2}$, but as in the case of the unsupported samples, $\mathrm{H}_{5} \mathrm{PV}_{2} \mathrm{Mo}_{10} \mathrm{O}_{40}$ clusters were more selective for DMM synthesis 

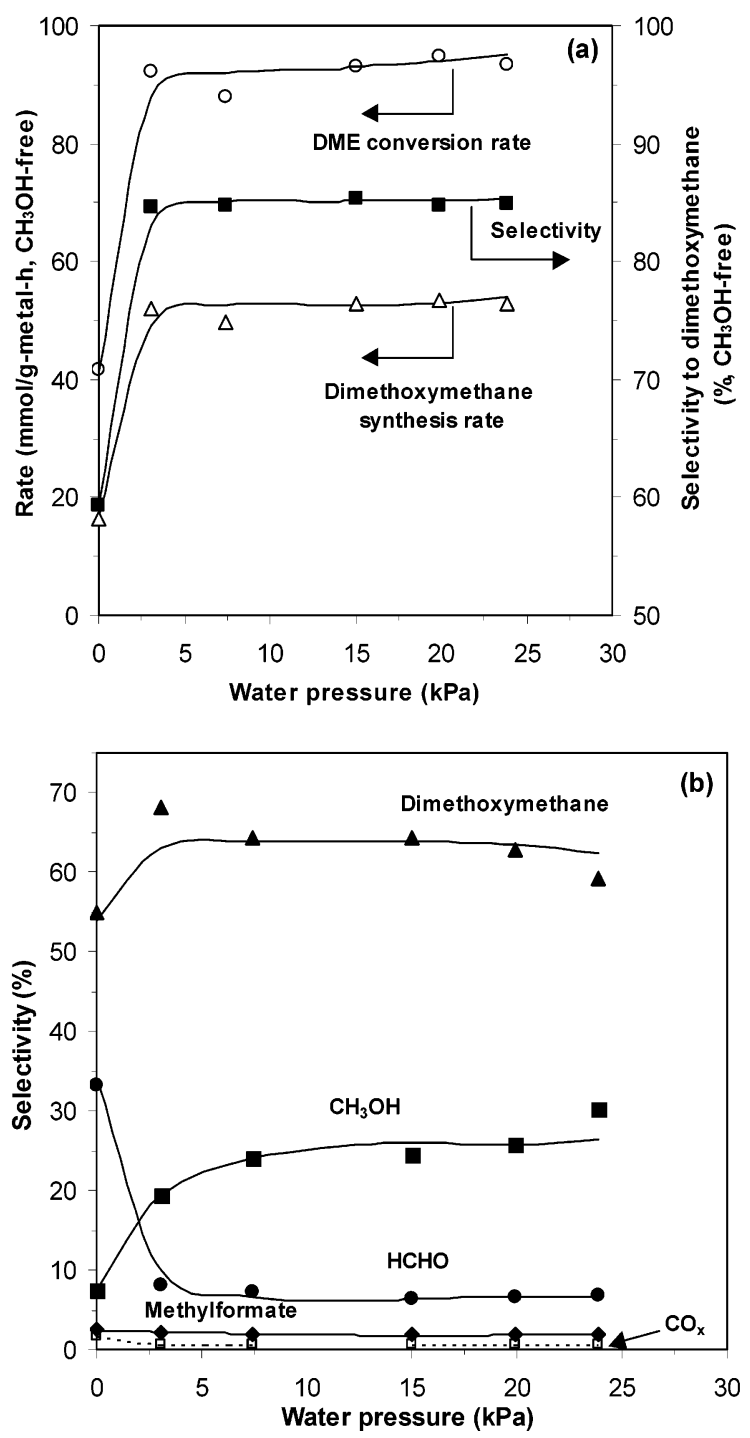

Figure 1. Effects of $\mathrm{H}_{2} \mathrm{O}$ partial pressure on oxidative DME reaction rates $\left(\mathrm{CH}_{3} \mathrm{OH}\right.$-free) (a) and selectivities (b) as well as on $\mathrm{CH}_{3} \mathrm{OH}$-free dimethoxymethane selectivities (a) at $513 \mathrm{~K}$ on $\mathrm{H}_{5} \mathrm{PV}_{2} \mathrm{Mo}_{10} \mathrm{O}_{40} / \mathrm{SiO}_{2}$ $(9.2 \mathrm{wt} \%)$ treated at $553 \mathrm{~K}\left(80 \mathrm{kPa}\right.$ DME, $18 \mathrm{kPa} \mathrm{O}_{2}, 2 \mathrm{kPa} \mathrm{N}_{2}$, balance $\mathrm{He})$.

than $\mathrm{H}_{3} \mathrm{PMo}_{12} \mathrm{O}_{40}$ structures. These supported catalysts showed much lower selectivities to $\mathrm{CO}_{x}$ than the corresponding bulk samples. On both supported catalysts, HCHO selectivities (22 or $33.2 \%$ ) were higher and DMM selectivities (44.6 or $55.0 \%$ ) were slightly lower than those in the respective bulk compounds. This may reflect the loss of some Brönsted acid sites during anchoring of Keggin clusters on supports or during subsequent thermal treatments, as also evidenced by the lower $\mathrm{CH}_{3} \mathrm{OH}$ selectivities observed on supported samples. On all samples, the relatively high $\mathrm{HCHO}$ selectivities appear to reflect the stoichiometric requirement for $\mathrm{CH}_{3} \mathrm{OH}$, which is present in low concentrations, for the final acetalization reaction of $\mathrm{HCHO}$ with $\mathrm{CH}_{3} \mathrm{OH}$ required in order to form DMM.

Figure 1 shows the effect of adding $\mathrm{H}_{2} \mathrm{O}$ to DME reactants during reactions on $\mathrm{H}_{5} \mathrm{PV}_{2} \mathrm{Mo}_{10} \mathrm{O}_{40} / \mathrm{SiO}_{2}(9.2 \mathrm{wt} \%$; treated at $553 \mathrm{~K})$. These experiments were performed to increase $\mathrm{CH}_{3}$ $\mathrm{OH}$ concentrations via acid-catalyzed DME hydration reactions and to allow the completion of the DMM synthesis sequence, which requires an acetalization step and a final step in which $\mathrm{CH}_{3} \mathrm{OH}$ reacts with $\mathrm{OH}$ groups in adsorbed adducts formed from $\mathrm{CH}_{3} \mathrm{OH}-\mathrm{HCHO}$ reactants as discussed in detail in the next section. DME conversion rates and DMM synthesis rates increased by factors of two and three, respectively, and the DMM selectivity increased from 55.0 to $68.3 \%$ (59.4 to $84.6 \%$, $\mathrm{CH}_{3} \mathrm{OH}$-free basis) as $3.1 \mathrm{kPa} \mathrm{H}_{2} \mathrm{O}$ was added to the $\mathrm{DME} / \mathrm{O}_{2}$ reactant stream. The selectivity to $\mathrm{CH}_{3} \mathrm{OH}$ increased concurrently from 7.4 to $19.3 \%$ as a result of the higher rate of DME hydration with increasing $\mathrm{H}_{2} \mathrm{O}$ concentration (Figure $1 \mathrm{~b}$ ). Higher $\mathrm{H}_{2} \mathrm{O}$ concentrations led to additional small increases in DME rates, mostly as a result of slightly higher DME hydration rates and the consequently higher $\mathrm{CH}_{3} \mathrm{OH}$ concentrations. The selectivity to DMM increased from 59.4 to $84.6 \%\left(\mathrm{CH}_{3} \mathrm{OH}-\right.$ free basis) as the $\mathrm{H}_{2} \mathrm{O}$ partial pressure increased to $3.1 \mathrm{kPa}$, but then remained essentially unchanged (84.7-85.3\%) for higher $\mathrm{H}_{2} \mathrm{O}$ partial pressures $\left(3.1-23.9 \mathrm{kPa}\right.$; Figure 1a). Similar $\mathrm{H}_{2} \mathrm{O}$ effects were observed on $\mathrm{H}_{3} \mathrm{PMo}_{12} \mathrm{O}_{40} / \mathrm{SiO}_{2}$. These general requirements for $\mathrm{CH}_{3} \mathrm{OH}$ as a co-reactant in DMM synthesis together with previous literature attempts at direct DMM synthesis from $\mathrm{CH}_{3} \mathrm{OH}$ led us to examine this reaction on supported heteropolyacids with Keggin structures.

3.2 Catalytic Oxidation of $\mathrm{CH}_{3} \mathrm{OH}$ on Heteropolyacids with Keggin Structures. Effects of $\mathrm{H}_{3+n} \mathrm{PV}_{n} \mathrm{Mo}_{12-n} \mathrm{O}_{40} \mathrm{Com}$ position on Oxidative $\mathrm{CH}_{3} \mathrm{OH}$ Reactions. The main products formed from $\mathrm{CH}_{3} \mathrm{OH}$ reactions on $\mathrm{H}_{3+n} \mathrm{PV}_{n} \mathrm{Mo}_{12-n} \mathrm{O}_{40}(n=$ $0,1,2,4)$ were $\mathrm{HCHO}$, dimethoxymethane, methylformate, and DME (Table 2). At these conditions, $\mathrm{CO}_{x}(\mathrm{CO}$ is $>90 \%$ of the $\mathrm{CO}_{x}$ formed) selectivities were very low $(<5 \%)$ even at $\mathrm{CH}_{3}-$ $\mathrm{OH}$ conversions of nearly $70 \%$. Table 2 shows $\mathrm{CH}_{3} \mathrm{OH}$ conversion rates (DME-free) and selectivities obtained at 493 $\mathrm{K}$ on unsupported and $\mathrm{SiO}_{2}$-supported $\mathrm{H}_{3+n} \mathrm{PV}_{n} \mathrm{Mo}_{12-n} \mathrm{O}_{40}(n$ $=0,1,2,4)$ catalysts. These materials were treated in dry air at $553 \mathrm{~K}$; the effects of thermal pretreatment temperature are described below. Reaction rates are reported normalized per Keggin unit (molecules/KU-h) and per gram of the active element (mmol/g-metal-h). Selectivities are reported both by considering DME as a products and also on a DME-free basis, in view of available pathways for DME conversion to similar products and to $\mathrm{CH}_{3} \mathrm{OH}$ on these catalysts. At similar $\mathrm{CH}_{3} \mathrm{OH}$ conversions, reaction rates on the three unsupported heteropolyacids were only weakly influenced by the V/Mo content. DMM was the predominant product of oxidative $\mathrm{CH}_{3} \mathrm{OH}$ reactions on all three catalysts and DMM selectivities reached values of 75$81 \%$ (DME-free basis at $22-25 \% \mathrm{CH}_{3} \mathrm{OH}$ conversion).

The replacement of some Mo atoms by $\mathrm{V}$ to form $\mathrm{H}_{4}$ $\mathrm{PVMo}_{11} \mathrm{O}_{40}$ and $\mathrm{H}_{5} \mathrm{PV}_{2} \mathrm{Mo}_{10} \mathrm{O}_{40}$ led to higher DMM selectivities and to lower MF selectivities, as shown in Table 2. The combined selectivity to desired DMM and $\mathrm{HCHO}$ products reached values as high as $95 \%$ at $\mathrm{CH}_{3} \mathrm{OH}$ conversions of $22 \%$ (both DME-free basis). High DME selectivities ( 50\%) were also observed on all crystalline bulk heteropolyacid samples. Unsupported and supported $\mathrm{H}_{3} \mathrm{PW}_{12} \mathrm{O}_{40}$ were also tested for $\mathrm{CH}_{3} \mathrm{OH}-\mathrm{O}_{2}$ reactions and they led to the exclusive formation of DME from $\mathrm{CH}_{3} \mathrm{OH}$, consistent with their predominant function as acid catalysts (Table 2).

These materials were also tested as supported samples in order to increase their accessibility to reactants and $\mathrm{CH}_{3} \mathrm{OH}$ reaction rates. The results are shown in Table $2 . \mathrm{CH}_{3} \mathrm{OH}$ conversion rates increased by a factor of $\sim 40$ (both per Keggin unit and per mass of active component). $\mathrm{H}_{4} \mathrm{PVMo}_{11} \mathrm{O}_{40}$ clusters supported on $\mathrm{SiO}_{2}$ were slightly more active than supported $\mathrm{H}_{3} \mathrm{PMo}_{12} \mathrm{O}_{40}$, $\mathrm{H}_{5} \mathrm{PV}_{2} \mathrm{Mo}_{10} \mathrm{O}_{40}$, and $\mathrm{H}_{6} \mathrm{PV}_{4} \mathrm{Mo}_{8} \mathrm{O}_{40}$ clusters. The selectivity to DME was lower on supported catalysts than on unsupported catalysts, possibly as a result of the loss of some acid sites during anchoring of the Keggin clusters via reaction of their $\mathrm{OH}$ groups with $\mathrm{Si}-\mathrm{OH}$ groups on $\mathrm{SiO}_{2}$ surfaces. DMM selectivities of $\sim 84 \%$ were reached on both $\mathrm{H}_{5} \mathrm{PV}_{2} \mathrm{Mo}_{10} \mathrm{O}_{40} / \mathrm{SiO}_{2}$ and $\mathrm{H}_{4-}$ 
TABLE 2: $\mathrm{CH}_{3} \mathrm{OH}$ Oxidation on Unsupported and $\mathrm{SiO}_{2}$-Supported Heteropoly Acid Catalysts at $493 \mathrm{~K}^{a}$ and on Other Literature Catalysts for Comparison

\begin{tabular}{|c|c|c|c|c|c|c|c|c|c|}
\hline \multirow[b]{2}{*}{ catalyst } & \multirow{2}{*}{$\begin{array}{c}\text { conversion } \\
(\%)^{b}\end{array}$} & \multirow{2}{*}{$\begin{array}{c}\text { rate (DME-free) } \\
\text { (molecules/KU-h) }\end{array}$} & \multirow{2}{*}{$\begin{array}{c}\text { rate } \\
(\mathrm{mmol} / \mathrm{g}-\mathrm{metal}-\mathrm{h})\end{array}$} & \multicolumn{5}{|c|}{ selectivity $(\%)^{b}$} & \multirow[b]{2}{*}{ refs } \\
\hline & & & & $\overline{\mathrm{DME}}$ & $\mathrm{HCHO}$ & MF & DMM & $\mathrm{CO}_{x}$ & \\
\hline $\mathrm{H}_{3} \mathrm{PMo}_{12} \mathrm{O}_{40}$ & $\begin{array}{l}52.6 \\
(24.6)\end{array}$ & 6.2 & $5.1^{c}$ & 52.2 & $\begin{array}{c}4.2 \\
(8.8)\end{array}$ & $\begin{array}{c}4.2 \\
(9.3)\end{array}$ & $\begin{array}{l}34.6 \\
(72.3)\end{array}$ & $\begin{array}{c}5.0 \\
(10.4)\end{array}$ & this work \\
\hline $\mathrm{H}_{4} \mathrm{PVMo}_{11} \mathrm{O}_{40}$ & $\begin{array}{l}44.2 \\
(21.2)\end{array}$ & 5.3 & $4.8^{c}$ & 52.1 & $\begin{array}{c}6.5 \\
(13.6)\end{array}$ & $\begin{array}{c}0.7 \\
(1.4)\end{array}$ & $\begin{array}{l}38.8 \\
(81.1)\end{array}$ & $\begin{array}{l}1.7 \\
(3.5)\end{array}$ & this work \\
\hline $\mathrm{H}_{5} \mathrm{PV}_{2} \mathrm{Mo}_{10} \mathrm{O}_{40}$ & $\begin{array}{l}41.6 \\
(22.4)\end{array}$ & 5.5 & $5.2^{c}$ & 48.1 & $\begin{array}{c}8.7 \\
(16.8)\end{array}$ & $\begin{array}{c}0.4 \\
(0.8)\end{array}$ & $\begin{array}{l}40.2 \\
(77.5)\end{array}$ & $\begin{array}{c}2.6 \\
(5.0)\end{array}$ & this work \\
\hline $\mathrm{H}_{3} \mathrm{PW}_{12} \mathrm{O}_{40}$ & $\begin{array}{c}43.2 \\
\text { (trace) }\end{array}$ & - & $-c$ & 100 & 0 & 0 & trace & trace & this work \\
\hline $\begin{array}{l}\mathrm{H}_{3} \mathrm{PMo}_{12} \mathrm{O}_{40} / \mathrm{SiO}_{2} \\
(9.3 \text { wt \%) }\end{array}$ & $\begin{array}{l}68.5 \\
(45.7)\end{array}$ & 248.7 & $205.7^{c}$ & 33.3 & $\begin{array}{c}7.6 \\
(11.4)\end{array}$ & $\begin{array}{c}11.9 \\
(17.9)\end{array}$ & $\begin{array}{l}41.0 \\
(61.5)\end{array}$ & $\begin{array}{c}5.5 \\
(8.3)\end{array}$ & this work \\
\hline $\begin{array}{l}\mathrm{H}_{4} \mathrm{PVMo}_{11} \mathrm{O}_{40} / \mathrm{SiO}_{2} \\
(9.2 \mathrm{wt} \%)\end{array}$ & $\begin{array}{c}68.2 \\
(47.0)\end{array}$ & 254.2 & $232.0^{c}$ & 31.1 & $\begin{array}{c}3.2 \\
(4.6)\end{array}$ & $\begin{array}{c}5.6 \\
(8.1)\end{array}$ & $\begin{array}{l}58.1 \\
(84.3)\end{array}$ & $\begin{array}{l}1.0 \\
(1.5)\end{array}$ & this work \\
\hline $\begin{array}{l}\mathrm{H}_{5} \mathrm{PV}_{2} \mathrm{Mo}_{10} \mathrm{O}_{40} / \mathrm{SiO}_{2} \\
(9.2 \text { wt \%) }\end{array}$ & $\begin{array}{c}63.3 \\
(40.9)\end{array}$ & 217.4 & $206.8^{c}$ & 35.4 & $\begin{array}{l}4.5 \\
(6.9)\end{array}$ & $\begin{array}{l}4.0 \\
(6.2)\end{array}$ & $\begin{array}{l}54.0 \\
(83.6)\end{array}$ & $\begin{array}{c}0.3 \\
(0.4)\end{array}$ & this work \\
\hline $\begin{array}{l}\mathrm{H}_{6} \mathrm{PV}_{4} \mathrm{Mo}_{8} \mathrm{O}_{40} / \mathrm{SiO}_{2} \\
(10.2 \%)\end{array}$ & $\begin{array}{c}60.3 \\
(41.8)\end{array}$ & 143.9 & 154.2 & 30.7 & $\begin{array}{l}10.7 \\
(15.4)\end{array}$ & $\begin{array}{c}2.4 \\
(3.5)\end{array}$ & $\begin{array}{c}55.1 \\
(79.5)\end{array}$ & 0 & this work \\
\hline $\begin{array}{l}\mathrm{H}_{3} \mathrm{PW}_{12} \mathrm{O}_{40} / \mathrm{SiO}_{2} \\
(9.7 \%)\end{array}$ & $\begin{array}{c}92.8 \\
(\sim 0.2)\end{array}$ & - & $-c$ & 99.8 & 0 & 0 & $\begin{array}{l}\sim 0.1 \\
(61.5)\end{array}$ & $\begin{array}{l}\sim 0.1 \\
(38.5)\end{array}$ & this work \\
\hline $\mathrm{SbRe}_{2} \mathrm{O}_{6}{ }^{d}$ & 6.5 & - & $\sim 1.1$ & 6.5 & 0 & 1.2 & 92.5 & 0 & 3 \\
\hline $\begin{array}{l}\mathrm{ReO}_{x} / \mathrm{Fe}_{2} \mathrm{O}_{3}{ }^{e} \\
(10 \text { wt } \operatorname{Re} \%)\end{array}$ & 48.4 & - & 319.2 & 1.0 & 2.4 & 4.6 & 91.0 & 1.0 & 4 \\
\hline $\mathrm{PMo} / \mathrm{SiO}_{2}^{f}$ & - & - & - & $\sim 7$ & $\sim 16$ & $\sim 20$ & $\sim 55$ & $\sim 2$ & 6 \\
\hline
\end{tabular}

${ }^{a}$ Reactant mixture: $4 \mathrm{kPa} \mathrm{CH} \mathrm{CH}_{3}, 9 \mathrm{kPa} \mathrm{O}, 1 \mathrm{kPa} \mathrm{N}_{2}$, balance He. ${ }^{b}$ Data in parentheses are calculated on a DME-free basis. ${ }^{c}$ Data are calculated on a DME-free basis. ${ }^{d}$ Reaction mixture: $\mathrm{CH}_{3} \mathrm{OH} / \mathrm{O}_{2} / \mathrm{He}=4.0 / 9.7 / 86.3$ (mol \%); reaction temperature: $573 \mathrm{~K} .{ }^{e}$ Reaction mixture: $\mathrm{CH}_{3} \mathrm{OH} / \mathrm{O}_{2} / \mathrm{He}=4.0 / 9.7 / 86.3$ (mol \%); reaction temperature: $513 \mathrm{~K} .{ }^{f}$ Reaction mixture: $\mathrm{CH}_{3} \mathrm{OH} / \mathrm{O}_{2} / \mathrm{He}=4.5 / 10.3 / 85.2$ (mol \%); reaction temperature: $513 \mathrm{~K}$; catalysts treated at $593 \mathrm{~K}$.

$\mathrm{PVMo}_{11} \mathrm{O}_{40} / \mathrm{SiO}_{2}$ samples at $\mathrm{CH}_{3} \mathrm{OH}$ conversions of $40.9-$ $47.0 \%$, with extremely low $\mathrm{CO}_{x}$ selectivities $(0.4-1.5 \%)$.

Comparison with State-of-the-Art Catalysts for One-Step DMM Synthesis from $\mathrm{CH}_{3} \mathrm{OH}$. The best reported catalysts for direct $\mathrm{CH}_{3} \mathrm{OH}$ oxidation to DMM are based on supported Re oxides. ${ }^{4} \mathrm{CH}_{3} \mathrm{OH}$ reaction rates (per gram active component, DME-free basis) measured on $\mathrm{H}_{4} \mathrm{PVMo}_{11} \mathrm{O}_{40} / \mathrm{SiO}_{2}$ and $\mathrm{H}_{5} \mathrm{PV}_{2^{-}}$ $\mathrm{Mo}_{10} \mathrm{O}_{40} / \mathrm{SiO}_{2}$ catalysts are similar to the highest values reported on supported $\mathrm{ReO}_{x}$ catalysts (Table 2). DMM selectivities were also similar when compared on a DME-free basis, but the large number of acid sites and strong acidity of heteropolyacid materials led to higher DME selectivities during $\mathrm{CH}_{3} \mathrm{OH}$ reactions. Our evaluation of some of the $\mathrm{ReO}_{x}$-based compositions reported in $\mathrm{CH}_{3} \mathrm{OH}$ reactions led to significantly higher DME selectivities than previously reported. ${ }^{4}$ It also led to the extensive sublimation of $\mathrm{ReO}_{x}$ species, consistent with the high volatility of the prevalent $\mathrm{ReO}_{x}$ species at the required reaction conditions. Several other studies have detected DMM products either with very low selectivity or very low formation rate. ${ }^{5-7,11}$ For example, $\mathrm{H}_{3} \mathrm{PMo}_{12} \mathrm{O}_{40}$ clusters supported on $\mathrm{SiO}_{2}(5.75 \mathrm{wt}$ $\% \mathrm{Mo})$ gave DMM selectivities as high as $55 \%$ at $513 \mathrm{~K}$ after the sample was treated at $593 \mathrm{~K}$ (Table 2), but $\mathrm{CH}_{3} \mathrm{OH}$ conversion rates were not reported, thus preventing direct comparisons with our results reported here. ${ }^{6} \mathrm{Mo} / \mathrm{MCM}-41$ (2 mol \% Mo) showed a high DMM selectivity (72.6\%) and very low $\mathrm{CH}_{3} \mathrm{OH}$ conversion $(0.7 \%)$ at $543 \mathrm{~K}$, but Mo migration out of MCM channels led to rapid deactivation. ${ }^{7}$

The partial conversion of $\mathrm{CH}_{3} \mathrm{OH}$ to DME during DMM synthesis does not present significant hurdles, because pathways are available for the re-formation of $\mathrm{CH}_{3} \mathrm{OH}$ as it is depleted and for DME conversion to $\mathrm{HCHO}$ and DMM products on heteropolyacids (Tables 1, Figure 1) and to HCHO on supported $\mathrm{MoO}_{x}$ and $\mathrm{VO}_{x}$ catalysts. ${ }^{15-18}$ Finally, the selectivity to DME can be further decreased by the selective titration of some of the Brönsted acid sites in heteropolyacids or by their partial dehydroxylation during controlled thermal treatments, as described in the next section.

Effects of $\mathrm{H}_{5} \mathrm{PV}_{2} \mathrm{Mo}_{10} \mathrm{O}_{40}$ Surface Density and Thermal Treatment on $\mathrm{CH}_{3} \mathrm{OH}$ Reaction Rate and Selectivity. The catalytic properties of supported heteropolyacids depend on their dispersion on $\mathrm{SiO}_{2}$. Table 3 shows the effects of $\mathrm{H}_{5} \mathrm{PV}_{2} \mathrm{Mo}_{10} \mathrm{O}_{40}$ loading and surface density on the rate and selectivity of $\mathrm{CH}_{3}$ $\mathrm{OH}$ oxidation reactions. Surface densities are reported as the number of Keggin units or the number of $\mathrm{V}$ and Mo active metal atoms per BET surface area $\left(\mathrm{KU} / \mathrm{nm}^{2}\right.$ and metal $\left./ \mathrm{nm}^{2}\right)$. For loadings less than $9.2 \mathrm{wt} \%$, reaction rates remained nearly constant with loading, indicating that most, and possibly all, Keggin clusters are accessible to reactants in this surface coverage range. Higher surface densities led to a decrease in $\mathrm{CH}_{3} \mathrm{OH}$ reaction rates (per $\mathrm{KU}$ ), apparently because of incipient agglomeration of dispersed Keggin units into clusters with secondary crystalline structures. The surface densities required for incipient agglomeration $\left(0.10-0.28 \mathrm{KU} / \mathrm{nm}^{2}\right)$ are smaller than those estimated from geometric arguments for a theoretical monolayer of Keggin clusters $\left(0.7 \mathrm{KU} / \mathrm{nm}^{2}\right)$, each one of which occupies $\sim 1.44 \mathrm{~nm}^{2}$. The samples with the lowest surface density $\left(0.024 \mathrm{KU} / \mathrm{nm}^{2}\right)$ gave very low DME selectivity $(20.4 \%)$ and high $\mathrm{HCHO}$ selectivity. Increasing the surface density to $0.10 \mathrm{KU} / \mathrm{nm}^{2}$ led to higher DME and DMM selectivities and lower HCHO selectivities. At surface densities of $0.65 \mathrm{KU} / \mathrm{nm}^{2}$, DMM selectivities decreased and $\mathrm{HCHO}$ selectivities increased. It appears that protons are consumed in condensation reactions leading to the anchoring of Keggin clusters at low $\mathrm{H}_{5} \mathrm{PV}_{2}$ $\mathrm{Mo}_{10} \mathrm{O}_{40}$ surface densities and that the Keggin clusters may behave similarly to bulk $\mathrm{H}_{5} \mathrm{~V}_{2} \mathrm{Mo}_{10} \mathrm{O}_{40}$ crystallites as surface densities increase beyond monolayer coverages.

Keggin clusters dehydroxylate via condensation reactions that convert $\mathrm{OH}$ groups into $\mathrm{H}_{2} \mathrm{O}$ and form $\mathrm{Mo}-\mathrm{O}-$ Mo linkages between Keggin units and ultimately destroy the primary Keggin structure to form crystalline $\mathrm{MoO}_{3}$. These reactions occur 
TABLE 3: Effects of $\mathrm{H}_{5} \mathrm{PV}_{2} \mathrm{Mo}_{10} \mathrm{O}_{40} \cdot 30 \mathrm{H}_{2} \mathrm{O}$ Content of $\mathrm{H}_{5} \mathrm{PV}_{2} \mathrm{Mo}_{10} \mathrm{O}_{40} / \mathrm{SiO}_{2}$ on $\mathrm{CH}_{3} \mathrm{OH}$ Oxidation $(493 \mathrm{~K}, 4 \mathrm{kPa} \mathrm{DME}, 9 \mathrm{kPa}$ $\mathrm{O}_{2}, 1 \mathrm{kPa} \mathrm{N}$, Balance $\left.\mathrm{He}\right)$

\begin{tabular}{|c|c|c|c|c|c|c|c|c|c|c|c|}
\hline \multirow{2}{*}{$\begin{array}{l}\text { content } \\
\text { (wt \%) }\end{array}$} & \multirow{2}{*}{$\begin{array}{c}\mathrm{SA} \\
\left(\mathrm{m}^{2} / \mathrm{g}\right)\end{array}$} & \multirow{2}{*}{$\begin{array}{c}\mathrm{SD} \\
\mathrm{KU} / \mathrm{nm}^{2}\end{array}$} & \multirow{2}{*}{$\begin{array}{c}\mathrm{SD} \\
\mathrm{Mo}+\mathrm{V} / \mathrm{nm}^{2}\end{array}$} & \multirow{2}{*}{$\begin{array}{l}\text { conversion } \\
(\%)^{a}\end{array}$} & \multirow{2}{*}{$\begin{array}{l}\text { rate (DME-free) } \\
\text { (molecules/KU-h) }\end{array}$} & \multirow{2}{*}{$\begin{array}{l}\text { rate (DME-free) } \\
(\mathrm{mmol} / \mathrm{g}-\mathrm{metal}-\mathrm{h})\end{array}$} & \multicolumn{5}{|c|}{ selectivity $(\%)^{a}$} \\
\hline & & & & & & & $\overline{\mathrm{DME}}$ & $\mathrm{HCHO}$ & MF & DMM & $\overline{\mathrm{CO}_{x}}$ \\
\hline 2.5 & 271.1 & 0.024 & 0.3 & $\begin{array}{c}27.2 \\
(21.6)\end{array}$ & 210.8 & 201.8 & 20.4 & $\begin{array}{c}21.4 \\
(26.9)\end{array}$ & $\begin{array}{c}4.6 \\
(5.8)\end{array}$ & $\begin{array}{c}52.7 \\
(66.3)\end{array}$ & 0 \\
\hline 5.1 & 263.3 & 0.051 & 0.6 & $\begin{array}{l}33.7 \\
(22.0)\end{array}$ & 210.8 & 201.0 & 34.7 & $\begin{array}{c}14.9 \\
(22.8)\end{array}$ & $\begin{array}{c}4.2 \\
(6.4)\end{array}$ & $\begin{array}{c}45.8 \\
(70.1)\end{array}$ & 0 \\
\hline 9.2 & 236.2 & 0.10 & 1.2 & $\begin{array}{l}44.5 \\
(28.9)\end{array}$ & 230.7 & 219.2 & 35.0 & $\begin{array}{c}7.2 \\
(11.1)\end{array}$ & $\begin{array}{c}3.1 \\
(4.8)\end{array}$ & $\begin{array}{c}53.0 \\
(81.6)\end{array}$ & $\begin{array}{c}0.1 \\
(0.2)\end{array}$ \\
\hline 20.1 & 190.5 & 0.28 & 3.3 & $\begin{array}{c}41.3 \\
(26.2)\end{array}$ & 190.9 & 181.9 & 36.5 & $\begin{array}{c}8.1 \\
(12.8)\end{array}$ & $\begin{array}{l}2.7 \\
(4.3)\end{array}$ & $\begin{array}{c}51.2 \\
(80.6)\end{array}$ & 0 \\
\hline 35.0 & 143.1 & 0.65 & 7.8 & $\begin{array}{l}36.9 \\
(23.9)\end{array}$ & 150.0 & 142.7 & 35.2 & $\begin{array}{l}16.8 \\
(25.9)\end{array}$ & $\begin{array}{c}2.9 \\
(4.5)\end{array}$ & $\begin{array}{c}43.4 \\
(67.0)\end{array}$ & $\begin{array}{l}1.1 \\
(1.6)\end{array}$ \\
\hline
\end{tabular}

${ }^{a}$ Data in parentheses are calculated on a DME-free basis.

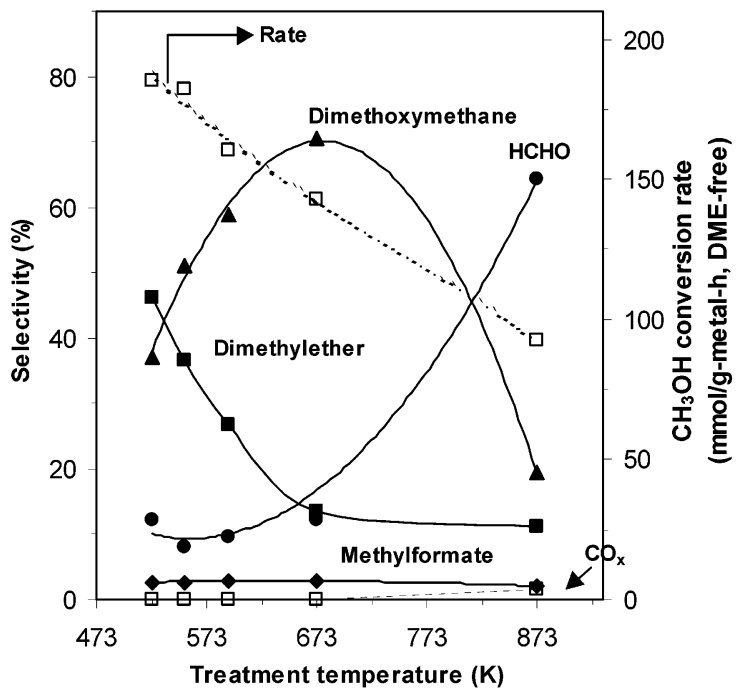

Figure 2. Effects of treatment temperature on $\mathrm{CH}_{3} \mathrm{OH}$ conversion rates (DME-free) and selectivities at $493 \mathrm{~K}$ on $\mathrm{H}_{5} \mathrm{PV}_{2} \mathrm{Mo}_{10} \mathrm{O}_{40} / \mathrm{SiO}_{2}(20.1$ wt \%; $4 \mathrm{kPa} \mathrm{CH}_{3} \mathrm{OH}, 9 \mathrm{kPa} \mathrm{O}, 1 \mathrm{kPa} \mathrm{N}$, balance $\mathrm{He}$ ).

between 550 and $670 \mathrm{~K}$ for bulk $\mathrm{H}_{5} \mathrm{PMo}_{12} \mathrm{O}_{40}$. The effects of thermal pretreatment on $\mathrm{CH}_{3} \mathrm{OH}$ reaction rate and selectivity on supported $\mathrm{H}_{5} \mathrm{~V}_{2} \mathrm{Mo}_{10} \mathrm{O}_{40}$ were explored and the results are shown in Figure 2. Thermal treatments of $\mathrm{H}_{5} \mathrm{PV}_{2} \mathrm{Mo}_{10} \mathrm{O}_{40} / \mathrm{SiO}_{2}$ $(20.1 \mathrm{wt} \%)$ in air at $523 \mathrm{~K}$ led to high DME selectivities (46.2\%) and to relatively low DMM selectivities of $37.1 \%$ (69.0\%, DME-free). As the thermal treatment temperature increased to $553 \mathrm{~K}$, the DME selectivity declined to $36.5 \%$, while the DMM selectivity increased to $51.2 \%$ (80.6\%, DMEfree). This trend continued until the treatment temperatures reached $\sim 673 \mathrm{~K}$. After treatment at $673 \mathrm{~K}$, the DME selectivity was $13.4 \%$, and the DMM selectivity was $70.5 \%$ (81.4\%, DMEfree). Further increases in the thermal treatment temperature ( 873 $\mathrm{K})$ led to a sharp decrease in DMM selectivity and to a concurrent increase in $\mathrm{HCHO}$ selectivity. The reaction rates (DME-free) decreased from $185.4 \mathrm{mmol} / \mathrm{g}$-metal-h to 143.0 $\mathrm{mmol} / \mathrm{g}$-metal-h by only $\sim 20 \%$ as the treatment temperature increased from 553 to $673 \mathrm{~K}$, but then decreased sharply to $92.4 \mathrm{mmol} / \mathrm{g}$-metal-h after treatment at $873 \mathrm{~K}$ (Figure 2).

These changes in the catalytic behavior of $\mathrm{H}_{5} \mathrm{PV}_{2} \mathrm{Mo}_{10} \mathrm{O}_{40} /$ $\mathrm{SiO}_{2}(9.2 \mathrm{wt} \%)$ upon thermal treatment are consistent with the observed structural evolution of $\mathrm{H}_{5} \mathrm{PV}_{2} \mathrm{Mo}_{10} \mathrm{O}_{40}$ Keggin units on $\mathrm{SiO}_{2}$ surfaces. Figure 3 shows Raman spectra for $\mathrm{H}_{5} \mathrm{PV}_{2}$ $\mathrm{Mo}_{10} \mathrm{O}_{40} / \mathrm{SiO}_{2}(9.2$ wt \%) after exposure to ambient air at 298 $\mathrm{K}$ and after treatment in dry air at various temperatures. The samples initially showed Raman bands at 1002 (s), 984 (sh), and $\sim 900(\mathrm{w}) \mathrm{cm}^{-1}$ in the $600-1100 \mathrm{~cm}^{-1}$ spectral region. The bands at 1002 and $984 \mathrm{~cm}^{-1}$ are assigned to terminal $\mathrm{Mo}=\mathrm{O}$

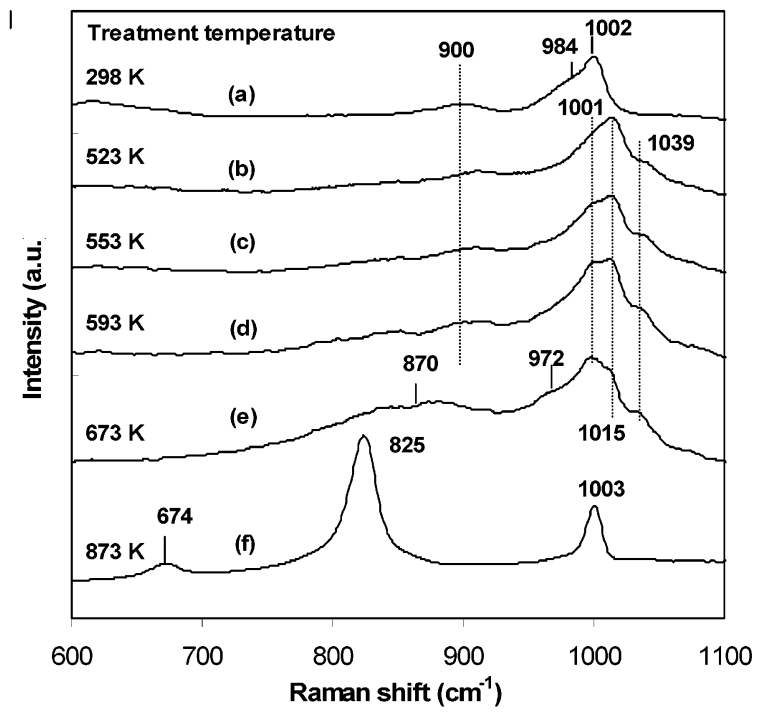

Figure 3. Raman spectra for $\mathrm{H}_{5} \mathrm{PV}_{2} \mathrm{Mo}_{10} \mathrm{O}_{40} / \mathrm{SiO}_{2}(20.1$ wt \%) at 298 $\mathrm{K}$ (a) and after thermal treatment in $20 \% \mathrm{O}_{2} / \mathrm{He}$ at $523 \mathrm{~K}$ (b), $553 \mathrm{~K}$ (c), $593 \mathrm{~K}(\mathrm{~d}), 673 \mathrm{~K}(\mathrm{e})$, and $873 \mathrm{~K}(\mathrm{f})$.

stretching vibrations, and the band around $900 \mathrm{~cm}^{-1}$ is assigned to bridging $\mathrm{Mo}-\mathrm{O}-\mathrm{Mo}$ (or $\mathrm{P}$ ) stretching modes in the intact Keggin structure ${ }^{19}$ The terminal $\mathrm{Mo}=\mathrm{O}$ stretching bands at 1002 and $984 \mathrm{~cm}^{-1}$ shifted to higher frequencies (1015 and 1001 $\mathrm{cm}^{-1}$, respectively) after treatment in $20 \% \mathrm{O}_{2} / \mathrm{He}$ at $523 \mathrm{~K}$; the band at $\sim 900 \mathrm{~cm}^{-1}$ remained unchanged, and a new weak band appeared at $1039 \mathrm{~cm}^{-1}$ (Figure 3, curve b). The observed shift to higher frequencies upon water desorption reflects a change in Mo coordination and in the bond order for terminal $\mathrm{Mo}=\mathrm{O}$ bonds associated with desorption of water molecules loosely coordinated to Keggin structure, ${ }^{19}$ as also found for dispersed $\mathrm{MoO}_{x}$ catalysts. ${ }^{18,20}$ The new band detected at $1039 \mathrm{~cm}^{-1}$ has been tentatively assigned to vanadyl species, which appear to form via expulsion of some $\mathrm{V}$-atoms from the Keggin structure after treatment at $\sim 523 \mathrm{~K} .{ }^{19}$ Increasing the treatment temperature from 523 to $553 \mathrm{~K}$ led to stronger features at $1001 \mathrm{~cm}^{-1}$ relative to those at $1015 \mathrm{~cm}^{-1}$, and this trend continued up to $673 \mathrm{~K}$. This phenomenon appears to reflect the loss of protons via dehydroxylation and the consequent formation of condensed Keggin structures after thermal treatment at 523-673 K. Treatment at $673 \mathrm{~K}$ led to two additional bands at 972 (w) and $\sim 870 \mathrm{~cm}^{-1}$ (b). After exposure to ambient moisture, the original spectrum in the starting material was restored (Figure 3, curve a), indicating that dehydroxylation processes are reversible at these temperatures and that destruction of the Keggin structure and formation of crystalline $\mathrm{MoO}_{3}$ does not occur upon dehydroxylation at $673 \mathrm{~K}$ or lower temperatures in these 


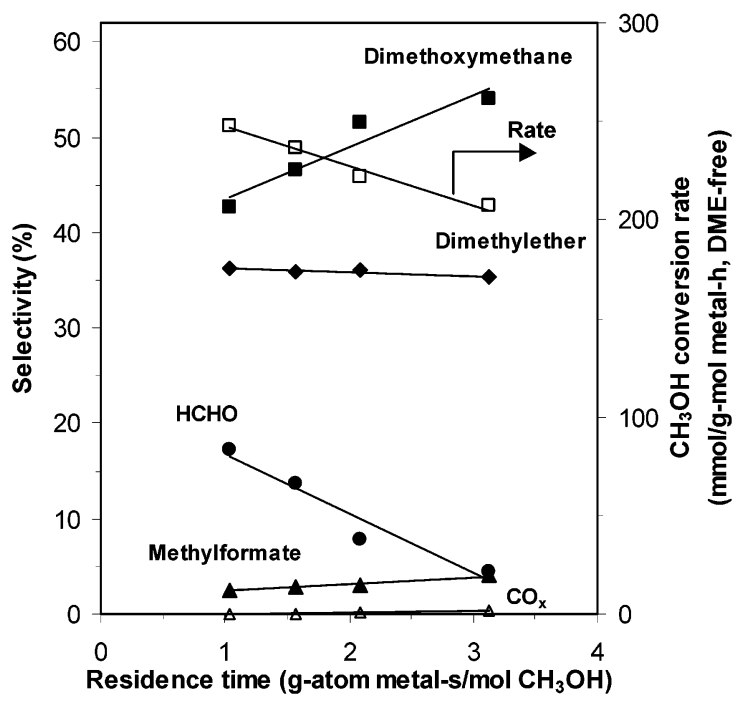

Figure 4. $\mathrm{CH}_{3} \mathrm{OH}$ reaction rates (DME-free) and selectivities as a function of reactant residence time at $493 \mathrm{~K}$ on $\mathrm{H}_{5} \mathrm{PV}_{2} \mathrm{Mo}_{10} \mathrm{O}_{40} / \mathrm{SiO}_{2}$ (9.2 wt \%) treated at $553 \mathrm{~K}\left(4 \mathrm{kPa} \mathrm{CH} 33 \mathrm{OH}, 9 \mathrm{kPa} \mathrm{O}_{2}, 1 \mathrm{kPa} \mathrm{N}\right.$, balance $\mathrm{He})$.

samples. Thermal treatments at $873 \mathrm{~K}$ led to the destruction of the Keggin structure in $\mathrm{H}_{5} \mathrm{PV}_{2} \mathrm{MoO}_{40}$ and to the irreversible formation of $\mathrm{MoO}_{3}$ crystallites (Figure 3, curve f), as shown by the characteristic Raman bands at 674,825 , and $1003 \mathrm{~cm}^{-1}, 20$ which remain after exposure to ambient moisture.

The dehydroxylated Keggin structures of $\mathrm{H}_{5} \mathrm{PV}_{2} \mathrm{MoO}_{40}$ formed after treatment at $\sim 673 \mathrm{~K}$ appear to provide an effective compromise between the redox sites required to form $\mathrm{HCHO}$ intermediates and the acid sites involved in acetalization $\mathrm{HCHO}-\mathrm{CH}_{3} \mathrm{OH}$ reactions to form DMM and in $\mathrm{CH}_{3} \mathrm{OH}$ dehydration to form DME. The ultimate decomposition of $\mathrm{H}_{5^{-}}$ $\mathrm{PV}_{2} \mathrm{MoO}_{40}$ into crystalline $\mathrm{MoO}_{3}$ and $\mathrm{V}_{2} \mathrm{O}_{5}$ removes all Brönsted acidity as all $\mathrm{OH}$ groups are removed as $\mathrm{H}_{2} \mathrm{O}$, but the materials retain some of the redox properties typical of Mo and $\mathrm{V}$ oxides and form $\mathrm{HCHO}$ with high selectivity, as in the case of $\mathrm{MoO}_{x^{-}}$and $\mathrm{VO}_{x}$-based $\mathrm{CH}_{3} \mathrm{OH}$ oxidation catalysts.

Dimethoxymethane Synthesis Pathways and Effects of Reactant Residence Time on Reaction Rates and Selectivities. Figure 4 shows $\mathrm{CH}_{3} \mathrm{OH}$ conversion rates and selectivities as a function of reactant residence time, which was changed by varying the reactant space velocity at $493 \mathrm{~K}$ on a $\mathrm{H}_{5} \mathrm{PV}_{2^{-}}$ $\mathrm{Mo}_{10} \mathrm{O}_{40} / \mathrm{SiO}_{2}(9.2 \mathrm{wt} \%)$ sample treated at $553 \mathrm{~K}$. The observed trends are similar on all supported and unsupported samples examined in this study.

$\mathrm{CH}_{3} \mathrm{OH}$ conversion rates decreased slightly with increasing residence time. This decrease reflects weak kinetic inhibition by water formed during oxidation reactions, as reported previously for DME oxidation to $\mathrm{HCHO}$ on $\mathrm{MoO}_{x}$ and $\mathrm{VO}_{x}$ catalysts. ${ }^{17}$ The selectivity to the predominant DMM product increased with increasing residence time and $\mathrm{CH}_{3} \mathrm{OH}$ conversion, while HCHO selectivity concurrently decreased. Selectivity to $\mathrm{MF}$ also increased with increasing residence time. The selectivity to $\mathrm{CO}_{x}$ was always very low $(<0.3 \%)$ and often undetectable. DME selectivities were essentially independent of residence time. The concurrent increase in DMM and MF selectivities and decrease in $\mathrm{HCHO}$ selectivity as residence time increases indicates that DMM and MF form via secondary $\mathrm{HCHO}$ reactions. The weak residence time effects on DME selectivity reflect its lower reactivity in oxidation reactions compared with $\mathrm{CH}_{3} \mathrm{OH}$, which is also present at much higher concentrations than DME at these conditions (cf. Tables 1 and 2 ). The observed effects of residence time on selectivity are

\section{SCHEME 1: Proposed $\mathrm{CH}_{3} \mathrm{OH}$ Reaction Pathways.}

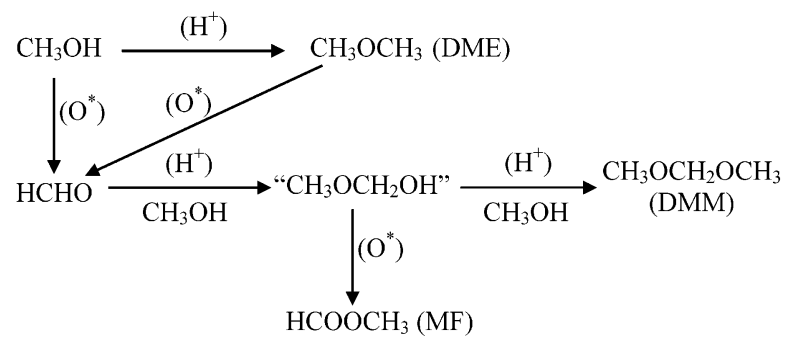

consistent with the reaction pathways shown in Scheme 1. These pathways include primary $\mathrm{CH}_{3} \mathrm{OH}$ reactions to form DME and $\mathrm{HCHO}$, and secondary reactions of $\mathrm{HCHO}$ to form DMM and MF via methoxymethanol or hemiacetal $\left(\mathrm{CH}_{3} \mathrm{OCH}_{2} \mathrm{OH}\right)$ intermediates, which form via acetalization reactions of $\mathrm{HCHO}$ with methoxide or methanol. ${ }^{21,22} \mathrm{CH}_{3} \mathrm{OCH}_{2} \mathrm{OH}$ intermediates were not detected during $\mathrm{CH}_{3} \mathrm{OH}$ reactions because of their thermodynamic instability and their expected rapid reactions with $\mathrm{CH}_{3}-$ $\mathrm{OH}$ to form DMM. These rapid reactions of $\mathrm{HCHO}$ and $\mathrm{CH}_{3} \mathrm{OCH}_{2} \mathrm{OH}$ intermediates with $\mathrm{CH}_{3} \mathrm{OH}$ make DMM appear to behave as a primary product, giving a nonzero extrapolated selectivity at zero residence time (Figure 4). The low measured $\mathrm{CO}_{x}$ selectivities $(<0.5 \%)$ allow us to exclude these steps from our kinetic analysis of these reaction pathways. DME oxidation kinetic measurements (Table 1 and Figure 1) suggest that secondary reactions of DME formed in $\mathrm{CH}_{3} \mathrm{OH}$ reactions can also form HCHO, which subsequently converts to DMM and MF (Scheme 1). These reaction pathways (Scheme 1) require the involvement of bifunctional pathways requiring both redox and acid sites. Redox sites with active lattice oxygen atoms catalyze initial oxidative dehydrogenation reactions of $\mathrm{CH}_{3} \mathrm{OH}$ or DME to form $\mathrm{HCHO}$, while acid sites $\left(\mathrm{H}^{+}\right)$are involved in the formation of $\mathrm{CH}_{3} \mathrm{OCH}_{2} \mathrm{OH}$ intermediates and in their conversion to DMM, as well as in $\mathrm{CH}_{3} \mathrm{OH}$ dehydration to form DME. These conclusions are consistent with the use of monofunctional acid catalysts for reactions of $\mathrm{HCHO}$ and $\mathrm{CH}_{3}-$ $\mathrm{OH}$ to form $\mathrm{DMM}^{23}$ and with parallel studies of the effects of titration of Brönsted acid sites with organic bases during $\mathrm{CH}_{3}$ $\mathrm{OH}$ oxidation reaction on these materials. ${ }^{24}$ Methylformate is likely to form via oxidative or non-oxidative dehydrogenation of $\mathrm{CH}_{3} \mathrm{OCH}_{2} \mathrm{OH}$ intermediates on redox sites. These findings and conclusions indicate that high $\mathrm{HCHO}$ concentrations, favored at high $\mathrm{CH}_{3} \mathrm{OH}$ conversions or high $\mathrm{CH}_{3} \mathrm{OH}$ inlet pressures, lead to higher DMM synthesis rates and selectivities, as a result of faster secondary acetalization reactions involving $\mathrm{HCHO}$ and $\mathrm{CH}_{3} \mathrm{OH}$, as shown in the next section.

Reactant Concentration and Temperature Effects on $\mathrm{CH}_{3} \mathbf{O H}$ Conversion to Dimethoxymethane. Table 4 shows the effects of reaction temperature on $\mathrm{CH}_{3} \mathrm{OH}$ conversion rates and selectivities on $\mathrm{H}_{5} \mathrm{PV}_{2} \mathrm{Mo}_{10} \mathrm{O}_{40} / \mathrm{SiO}_{2}(9.2 \mathrm{wt} \%)$ samples treated at $553 \mathrm{~K}$. Rates and selectivities are compared at similar $\mathrm{CH}_{3} \mathrm{OH}$ conversion levels ( $27 \%$, DME-free), which were achieved by varying reactant space velocities over a broad range. $\mathrm{CH}_{3} \mathrm{OH}$ reaction rates increased from $68 \mathrm{mmol} / \mathrm{g}$-metal-h to 340 $\mathrm{mmol} / \mathrm{g}$-metal-h as reaction temperatures increased from 453 to $513 \mathrm{~K}$. DMM selectivities decreased from 91.8\% (DMEfree) to $51.1 \%$ in this temperature range, mostly as a result of a concurrent increase in $\mathrm{HCHO}$ selectivity with increasing reaction temperature. These effects suggest that redox reactions leading to $\mathrm{HCHO}$ increase more strongly with temperature than acetalization reactions leading to DMM, suggesting a higher activation energy for the former reactions. DME and MF selectivities were only weakly affected by reaction temperature. 
TABLE 4: Effects of Reaction Temperature on $\mathrm{CH}_{3} \mathrm{OH}$ Oxidation on $\mathrm{H}_{5} \mathrm{PV}_{2} \mathrm{Mo}_{10} \mathrm{O}_{40} / \mathrm{SiO}_{2}\left(9.2 \mathrm{wt} \%, 4 \mathrm{kPa} \mathrm{DME}, 9 \mathrm{kPa} \mathrm{O}_{2}\right.$; Catalyst Sample Treated in Dry Air at 553 K)

\begin{tabular}{|c|c|c|c|c|c|c|c|}
\hline \multirow{2}{*}{$\begin{array}{l}\text { temperature } \\
\text { (K) }\end{array}$} & \multirow{2}{*}{$\begin{array}{l}\text { conversion } \\
(\%)^{a}\end{array}$} & \multirow{2}{*}{$\begin{array}{l}\text { rate (DME-free) } \\
(\mathrm{mmol} / \mathrm{g} \text {-metal-h) }\end{array}$} & \multicolumn{5}{|c|}{ selectivity $(\%)^{a}$} \\
\hline & & & $\overline{\mathrm{DME}}$ & $\mathrm{HCHO}$ & $\mathrm{MF}$ & DMM & $\mathrm{CO}_{x}$ \\
\hline 453 & $\begin{array}{l}39.9 \\
(26.9)\end{array}$ & 68.0 & 32.7 & $\begin{array}{c}2.1 \\
(3.1)\end{array}$ & $\begin{array}{c}3.2 \\
(4.8)\end{array}$ & $\begin{array}{c}61.8 \\
(91.8)\end{array}$ & 0 \\
\hline 473 & $\begin{array}{c}39.3 \\
(26.1)\end{array}$ & 132.0 & 33.6 & $\begin{array}{c}4.2 \\
(6.3)\end{array}$ & $\begin{array}{c}3.3 \\
(5.0)\end{array}$ & $\begin{array}{c}57.9 \\
(87.2)\end{array}$ & 0 \\
\hline 493 & $\begin{array}{c}45.2 \\
(28.9)\end{array}$ & 219.2 & 35.0 & $\begin{array}{c}7.2 \\
(11.1)\end{array}$ & $\begin{array}{c}3.1 \\
(4.8)\end{array}$ & $\begin{array}{c}53.0 \\
(81.6)\end{array}$ & $\begin{array}{c}0.1 \\
(0.2)\end{array}$ \\
\hline 513 & $\begin{array}{c}42.4 \\
(27.3)\end{array}$ & 340.4 & 36.0 & $\begin{array}{c}24.6 \\
(38.4)\end{array}$ & $\begin{array}{l}3.8 \\
(6.0)\end{array}$ & $\begin{array}{c}32.7 \\
(51.1)\end{array}$ & $\begin{array}{c}0.5 \\
(1.9)\end{array}$ \\
\hline
\end{tabular}

${ }^{a}$ Data in parentheses are calculated on a DME-free basis.

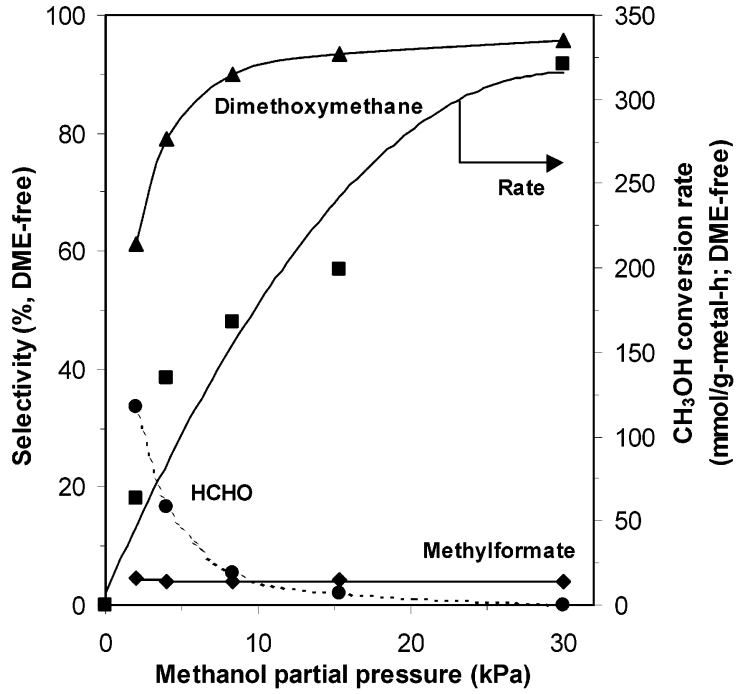

Figure 5. Effects of $\mathrm{CH}_{3} \mathrm{OH}$ partial pressure on $\mathrm{CH}_{3} \mathrm{OH}$ conversion rates and selectivities on a DME-free basis at $473 \mathrm{~K}$ on $\mathrm{H}_{5} \mathrm{PV}_{2} \mathrm{Mo}_{10} \mathrm{O}_{40} /$ $\mathrm{SiO}_{2}$ treated at $553 \mathrm{~K}(9.2 \mathrm{wt} \% ; 9 \mathrm{kPa} \mathrm{O}, 1 \mathrm{kPa} \mathrm{N}$, balance $\mathrm{He})$.

Figure 5 shows the effects of $\mathrm{CH}_{3} \mathrm{OH}$ partial pressure on $\mathrm{CH}_{3}-$ $\mathrm{OH}$ conversion rates and selectivities at $473 \mathrm{~K}$ on $\mathrm{H}_{5} \mathrm{PV}_{2-}$ $\mathrm{Mo}_{10} \mathrm{O}_{40} / \mathrm{SiO}_{2}(9.2 \mathrm{wt} \%$, treated at $553 \mathrm{~K})$. At similar $\mathrm{CH}_{3} \mathrm{OH}$ conversions ( $\sim 11 \%$ DME-free basis), reaction rates increased as $\mathrm{CH}_{3} \mathrm{OH}$ partial pressures increased from 2 to $30 \mathrm{kPa}$. Higher $\mathrm{CH}_{3} \mathrm{OH}$ partial pressures led to much lower $\mathrm{HCHO}$ selectivities and to a concurrent increase in DMM selectivities from $61.3 \%$ to $95.8 \%$ (DME-free). These trends appear to reflect the secondary nature of the pathways required for DMM synthesis, which require sequential bimolecular coupling reactions between $\mathrm{HCHO}$ and $\mathrm{CH}_{3} \mathrm{OH}$-derived intermediates and between the products formed in this reaction and $\mathrm{CH}_{3} \mathrm{OH}$ (Scheme 1). The enhancement of these secondary reactions with increasing $\mathrm{CH}_{3}$ $\mathrm{OH}$ partial pressure leads to higher $\mathrm{HCHO}$ conversion rates relative to its formation rate and to the observed decrease in $\mathrm{HCHO}$ selectivity as $\mathrm{CH}_{3} \mathrm{OH}$ inlet pressures increase. The concurrent observed increase in DME selectivity from $32.1 \%$ to $51.2 \%$ is consistent with the expected bimolecular nature of $\mathrm{CH}_{3} \mathrm{OH}$ dehydration reactions.

$\mathrm{CH}_{3} \mathrm{OH}$ reaction rates and selectivities were essentially unchanged as $\mathrm{O}_{2}$ partial pressures increased from 5 to $30 \mathrm{kPa}$ as shown in Figure 6. Such insensitivity to gas-phase $\mathrm{O}_{2}$ concentrations is typical of catalytic oxidation reactions proceeding via Mars van Krevelen pathways ${ }^{25}$ using lattice oxygen atoms. Such pathways have been established for $\mathrm{CH}_{3} \mathrm{OH}^{26}$ and $\mathrm{DME}^{17,18}$ oxidation to $\mathrm{HCHO}$ and for oxidative dehydrogenation of alkanes. ${ }^{27,28}$ The involvement of lattice oxygen atoms in $\mathrm{CH}_{3}$ -

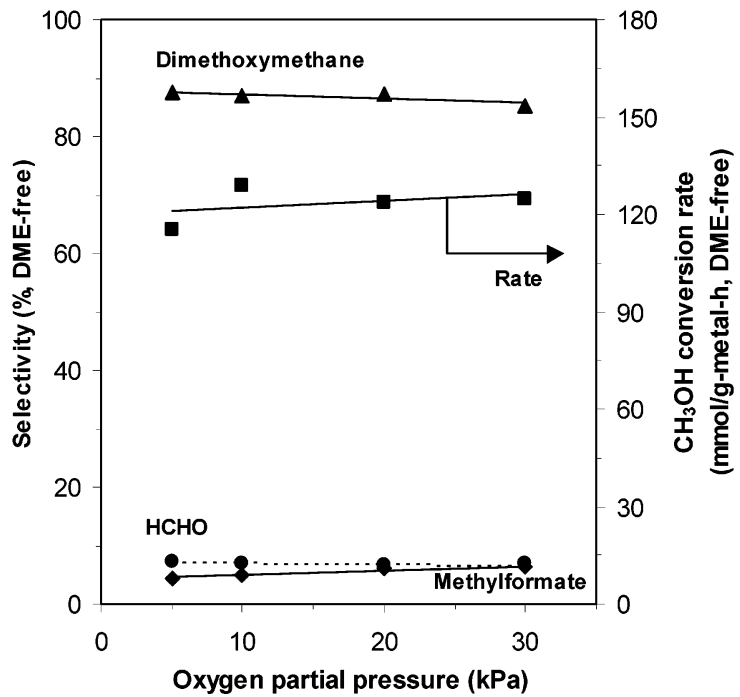

Figure 6. Effect of oxygen pressure on $\mathrm{CH}_{3} \mathrm{OH}$ conversion rates and selectivities on a DME-free basis at $473 \mathrm{~K}$ on $\mathrm{H}_{5} \mathrm{PV}_{2} \mathrm{Mo}_{10} \mathrm{O}_{40} / \mathrm{SiO}_{2}$ treated at $553 \mathrm{~K}\left(9.2 \mathrm{wt} \%\right.$; $4 \mathrm{kPa} \mathrm{CH} \mathrm{CH}_{3} \mathrm{OH}$, balance $\left.\mathrm{He}\right)$.

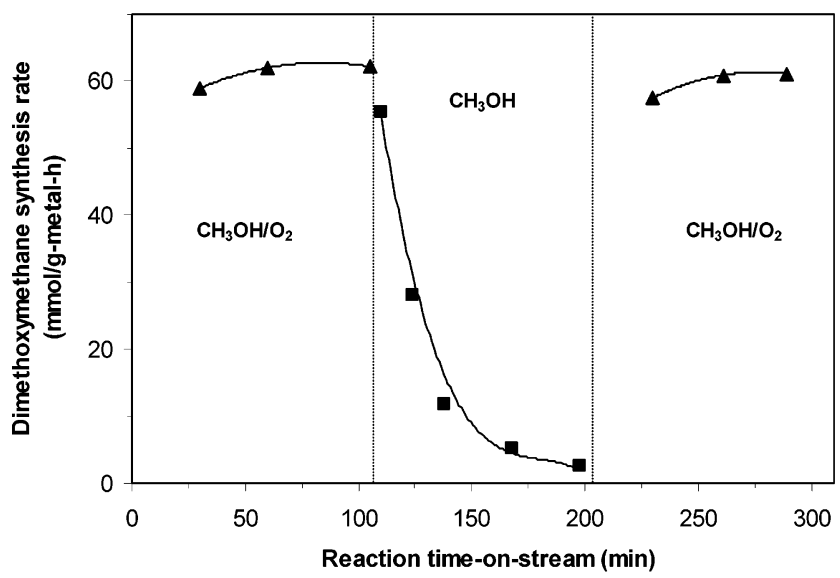

Figure 7. Dimethoxymethane synthesis rates in the presence and in the absence of gas-phase $\mathrm{O}_{2}$ at $453 \mathrm{~K}$ on a steady-state $\mathrm{H}_{5} \mathrm{PV}_{2} \mathrm{Mo}_{10} \mathrm{O}_{40} /$ $\mathrm{SiO}_{2}$ catalyst $(9.2 \mathrm{wt} \%)$ treated at $553 \mathrm{~K}\left(4 \mathrm{kPa} \mathrm{CH} \mathrm{CH}_{3} \mathrm{OH}, 9 \mathrm{kPa} \mathrm{O}_{2}\right.$ or no $\mathrm{O}_{2}$, balance $\mathrm{He}$ ).

$\mathrm{OH}$ conversion to DMM was confirmed by transient $\mathrm{CH}_{3} \mathrm{OH}$ reaction methods on $\mathrm{H}_{5} \mathrm{PV}_{2} \mathrm{Mo}_{10} \mathrm{O}_{40} / \mathrm{SiO}_{2}(9.2 \mathrm{wt} \%$, treated at $553 \mathrm{~K})$.

These transient experiments were conducted by carrying out steady-state $\mathrm{CH}_{3} \mathrm{OH}$ oxidation reactions on $\mathrm{H}_{5} \mathrm{PV}_{2} \mathrm{Mo}_{10} \mathrm{O}_{40} / \mathrm{SiO}_{2}$ catalysts and then removing the gas-phase $\mathrm{O}_{2}$. Figure 7 shows that the removal of $\mathrm{O}_{2}$ led to initial rates very similar to those obtained in the presence of $\mathrm{O}_{2}$ co-reactants, indicating that lattice oxygen is available for $\mathrm{CH}_{3} \mathrm{OH}$ conversion reactions. These rates decreased with time as lattice oxygen was depleted by these 
$\mathrm{CH}_{3} \mathrm{OH}$ oxidation reactions. The reintroduction of $\mathrm{O}_{2}$ led to the rapid and complete recovery of catalytic $\mathrm{CH}_{3} \mathrm{OH}$ conversion rates and selectivities. These findings are consistent with the involvement of lattice oxygen in $\mathrm{CH}_{3} \mathrm{OH}$ conversion to DMM and with the rapid reoxidation of the reduced centers formed during the reduction steps in the catalytic sequence, which in turn leads to the weak kinetic consequences of $\mathrm{O}_{2}$ pressures on DMM synthesis reactions.

\section{Conclusions}

The one-step selective synthesis of dimethoxymethane via oxidation of dimethyl ether or methanol with $\mathrm{O}_{2}$ was achieved at low temperatures $(453-513 \mathrm{~K})$ on unsupported and $\mathrm{SiO}_{2}$ supported heteropolyacids with $\mathrm{H}_{3+n} \mathrm{PV}_{n} \mathrm{Mo}_{12-n} \mathrm{O}_{40}(n=0-4)$ stoichiometry and Keggin cluster structures. The required bifunctional pathways benefit from the concurrent presence of redox and Brönsted acids, the ratio of which was varied by controlled thermal dehydroxylation of these Keggin clusters. The anchoring of these clusters on $\mathrm{SiO}_{2}$ supports increases the accessibility of acid and redox sites and the rate of $\mathrm{CH}_{3} \mathrm{OH}$ and $\mathrm{CH}_{3} \mathrm{OCH}_{3}$ conversion to dimethoxymethane. The replacement of some Mo atoms by $\mathrm{V}$ in $\mathrm{H}_{3+} \mathrm{PV}_{n} \mathrm{Mo}_{12-} \mathrm{O}_{40}$ increases the rate and selectivity of DMM synthesis from both reactants. $\mathrm{CO}_{x}$ formation is undetectable on several supported $\mathrm{H}_{3+n} \mathrm{PV}_{n^{-}}$ $\mathrm{Mo}_{12-n} \mathrm{O}_{40}$ compositions even at high $\mathrm{CH}_{3} \mathrm{OH}$ conversion (e.g. $\sim 45 \%$, DME-free). Controlled thermal dehydroxylation leads to partial loss of acid sites and to lower rates and selectivities for $\mathrm{CH}_{3} \mathrm{OH}$ dehydration side reactions. These dimethoxymethane selectivities (DME-free basis) and rates on $\mathrm{H}_{3+}{ }_{n} \mathrm{PV}_{n} \mathrm{Mo}_{12-n} \mathrm{O}_{40}$ clusters supported on $\mathrm{SiO}_{2}$ at $0.1-0.28 \mathrm{KU} / \mathrm{nm}^{2}$ surface densities are similar to those reported previously from $\mathrm{CH}_{3} \mathrm{OH}$ reactants on $\mathrm{ReO}_{x}$ catalysts. This study also represents the first report of dimethoxymethane synthesis from dimethyl ether. The required bifunctional pathways involve primary reactions of $\mathrm{CH}_{3} \mathrm{OH}$ or DME to form $\mathrm{HCHO}$ and secondary reaction of $\mathrm{HCHO}$ intermediates (formed in redox reactions) with $\mathrm{CH}_{3} \mathrm{OH}$ in acetalization and dehydration reactions leading to DMM. High $\mathrm{CH}_{3} \mathrm{OH}$ conversions and inlet pressures increase the concentrations of $\mathrm{HCHO}$ intermediates and favor secondary reactions and high DMM selectivities and yields.
Acknowledgment. This study was supported by BP as part of the Methane Conversion Cooperative Research Program at the University of California at Berkeley. We acknowledge helpful technical discussions with Drs. Theo Fleisch and John Collins of BP.

Note Added after ASAP Posting. This paper was posted ASAP on 9/10/2003. The middle initial given for Haichao Liu was in error; there is no middle initial. The corrected version was posted 9/16/2003.

\section{References and Notes}

(1) Hagen, G. P.; Spangler, M. J. U.S. Patent 6,265,528, 2001

(2) Hagen, G. P.; Spangler, M. J. U.S. Patent 6,437,195, 2002. $195,51$.

(3) Yuan, Y.; Liu H.; Imoto, H.; Shido, T.; Iwasawa, Y. J. Catal. 2000 4441 .

(4) Yuan, Y.; Shido, T.; Iwasawa, Y. J. Phys. Chem. B 2002, 106,

(5) Busca, G.; Elmi, A. S.; Forzatti P. J. Phys. Chem. 1987, 91, 5236.

(6) Rocchiccioli-Deltchff, C.; Aoussi, A.; Fournier, M. J. Mol. Catal. 1996, 114, 331

(7) Shannon, I. J.; Maschmeyer, T.; Oldroyd, R. D.; Sankar, G.; Thomas, J. M.; Che., M. J. Chem. Soc., Fraday, Trans. 1998, 94, 1495.

(8) Pope, M. T. "Heteropoly and Isopoly Oxometalates"; Springer: Berlin, 1983.

(9) Okuhara T.; Mizuno, N.; Misono, M. Adv. Catal. 1994, 41, 113.

(10) Mizuno, N.; Misono, M. Chem. Rev. 1994, 41, 113.

(11) Sorensen, C. M.; Weber, R. S. J. Catal. 1993, 142, 1.

(12) Li, J.-L.; Zhang, X.-G.; Inui, T. Appl. Catal., A 1996, 147, 23.

(13) Fleisch, T. H.; Basu, A.; Gradassi, M. J.; Masin, J. G. Stud. Surf. Sci. Catal. 1997, 107, 117.

(14) Shikada, T.; Ohno, Y.; Ogawa, T.; Ono, M.; Mizuguchi, M.; Tomura, K.; Fujimoto, K. Stud. Surf. Sci. Catal. 1998, 119, 515.

(15) Liu, H.; Iglesia, E. J. Catal. 2002, 208, 1.

(16) Liu, H.; Iglesia, E. U.S. Patent Application, February, 2002.

(17) Liu, H.; Cheung, P.; Iglesia, E. J. Phys. Chem. B 2003, 107, 4118.

(18) Liu, H.; Cheung, P.; Iglesia, E. J. Catal. 2003, 217, 222.

(19) Mestl, G.; Ilkenhans, T.; Spielbauer, D.; Dieterle, M.; Timpe, O.; Krohnert, J.; Jentoft, F.; Knozinger, H.; Schlogl, R. Appl. Catal., A 2001, $210,13$.

(20) Mestl, G.; Srinivasan, T. K. K. Catal. Rev. Sci. Eng. 1998, 38, 451.

(21) Wachs, I. E.; Madix, R. J. Surf. Sci. 1978, 76, 531.

(22) Louis, C.; Tatibouet, J.-M.; Che, M. J. Catal. 1988, 109, 354.

(23) Satoh, S.; Tanigawa, Y. U.S. Patent 6,379,507, 2002.

(24) Liu, H.; Bayat, N.; Iglesia, E. Angew. Chem. Int. Ed., in press

(25) Mars, P.; van Krevelen, D. W. Chem. Eng. Sci. 1954, 3, 41.

(26) Tatibouet, J. M. Appl. Catal., A 1997, 148, 213.

(27) Chen, K.; Iglesia, E.; Bell, A. T. J. Phys. Chem. B 2001, 105, 646.

(28) Chen, K.; Bell, A. T.; Iglesia, E. J. Catal. 2002, 209, 35. 